\title{
Sustainability Science \\ Governance of the water-energy-food nexus: insights from four infrastructure projects in the Lower Mekong Basin \\ --Manuscript Draft--
}

\begin{tabular}{|l|}
\hline Manuscript Number: \\
\hline Full Title: \\
\hline Article Type: \\
\hline Corresponding Author: \\
\hline Corresponding Author Secondary \\
Information: \\
\hline Corresponding Author's Institution: \\
\hline Corresponding Author's Secondary \\
Institution: \\
\hline First Author: \\
\hline First Author Secondary Information: \\
\hline Order of Authors: \\
\hline Funding Information: \\
\hline
\end{tabular}

Abstract:

Response to Reviewers:
SUST-D-19-00204R1

Governance of the water-energy-food nexus: insights from four infrastructure projects in the Lower Mekong Basin

Original Article

Louis Lebel, Ph.D.

Chiang Mai University

Chiang Mai, THAILAND

Chiang Mai University

Louis Lebel, Ph.D.

Louis Lebel, Ph.D.

Andrea Haefner, PhD

Claudia Pahl-Wostl, PhD

Anik Baduri, PhD

The social relations and biophysical flows that link water, food, and energy systems are said to form a 'nexus'. Efforts to steer or otherwise exert influence on decisions that impact upon these nexus links, including to ignore them, take place at multiple levels, vary in complexity, and have implications for who benefits and who is burdened by those relations and flows. This paper examines how nexus links have been governed using four medium- to large-scale water infrastructure projects in Laos and Thailand as probes into problematic issues of coordination, anticipation, inclusion and attribution. Project documents, media reports and published analyses were coded to extract information about nexus links, narratives and decisions. Nexus interactions were summarized using a novel symbolic notation and then classified along a scale of increasing structural complexity as pairs, chains, and loops. The key finding from the analysis of the four projects was that nexus governance was fragmented, reactive, exclusive and opaque. Coordination among ministries was limited with inter-ministerial bodies, and integrated development plans ineffective at guiding project design or operation decisions in the presence of bureaucratic competition. Anticipation of crosssectoral concerns was rare, despite scope to identify them early in feasibility studies and assessment activities; instead they were only acknowledged after public pressure. Inclusion of the needs of vulnerable and affected groups was limited, although poverty alleviation and other social benefits were a significant element in project justification narratives. Attribution of responsibility was difficult as many key decisions took place behind closed doors, while project information was withheld, raising further governance issues of transparency and accountability. Structural complexity in the nexus links made addressing governance problems even more challenging.

We have uploaded a responses to reviewers file in an easy to read table format where we address concerns point by point. 


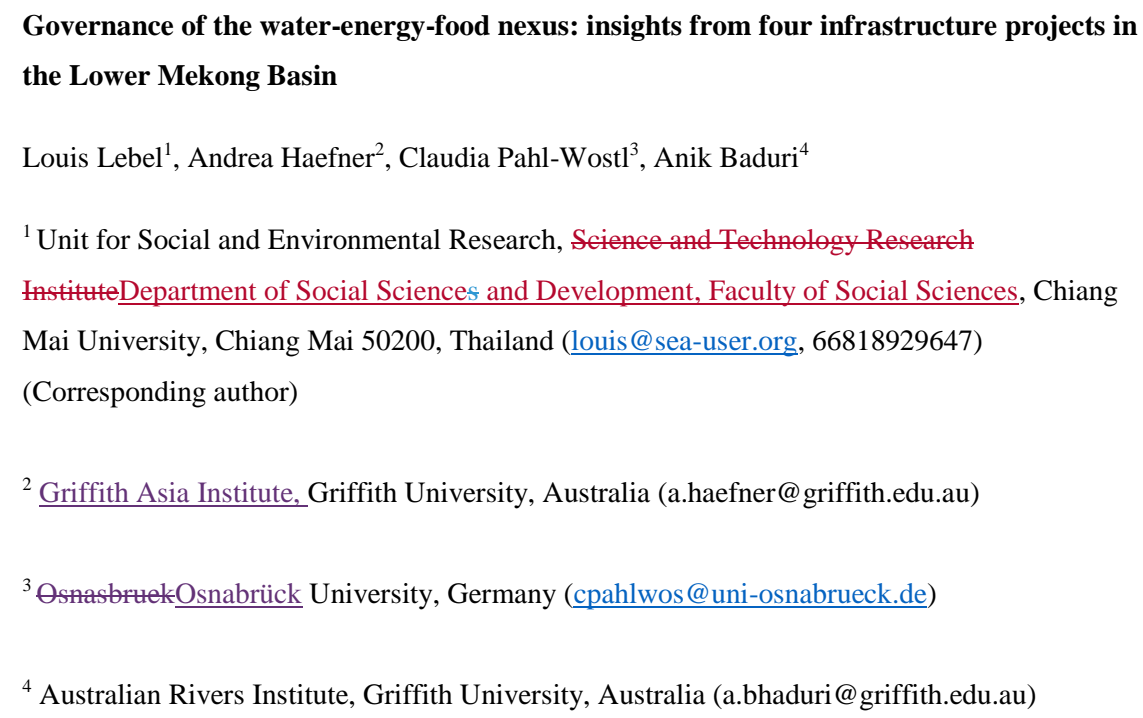

Acknowledgements. Thanks to FutureWater for support to LL and AH to develop the case studies, and to Christian Kneiper and Boripat Lebel for inputs on earlier drafts of this manuscript. 


\section{Abstract}

The social relations and biophysical flows that link water, food, and energy systems are said to form a 'nexus'. Efforts to steer or otherwise exert influence on decisions that impact upon these nexus links, including to ignore them, take place at multiple levels, vary in complexity, and have implications for who benefits and who is burdened by those relations and flows. This paper examines how nexus links have been governed using four medium- to large-scale water infrastructure projects in Laos and Thailand as probes into problematic issues of coordination, anticipation, inclusion and attribution.- Project documents, media reports and published analyses were coded to extract information about nexus links, narratives and decisions. Nexus interactions were summarized using a novel symbolic notation and then classified along a scale of increasing structural complexity as pairs, chains, and loops. The key finding from the analysis of the four projects was that nexus governance was fragmented, reactive, exclusive and opaque. Coordination among ministries was limited with inter-ministerial bodies, and integrated development plans ineffective at guiding project design or operation decisions in the presence of bureaucratic competition. Anticipation of cross-sectoral concerns was rare, despite scope to identify them early in feasibility studies and assessment activities; instead they were only acknowledged after public pressure. Inclusion of the needs of vulnerable and affected groups was limited, although poverty alleviation and other social benefits were a significant element in project justification narratives. Attribution of responsibility was difficult as many key decisions took place behind closed doors, while project information was withheld, raising further governance issues of transparency and accountability. Structural complexity in the nexus links made addressing governance problems even more challenging.

Keywords: water-energy-food nexus; water governance; hydropower; irrigation; Southeast Asia

\section{Introduction}

The social relations and biophysical flows that link water, food, and energy networks and systems are increasingly referred to as a 'nexus' as a way to draw attention to interactions and risks that actors perceive are neglected and important (Covarrubias, 2019; Leck et al., 2015; Smajgl et al., 2016). The nexus term is both a buzzword (Cairns and Krzywoszynska, 2016) and the cornerstone of emerging narratives in academic, business and policy communities (Lebel and Lebel, 2018; Leese and Meisch, 2015). The nexus term is applied to a diverse, often loosely defined, range of interactions among communities, nations, sectors and stakeholders (Leck et al., 2015; Leese and Meisch, 2015). As a consequence of these framing efforts, the nexus is emerging as another element of the politics around the allocation and management of water resources, particularly in situations where there are also significant concerns with energy and food insecurity (Keskinen et al., 2016; Villamayor-Tomas et al., 2015). 
Despite the rapid growth in interest in the water-energy-food nexus, and the proliferation of proposals and recommendations for technical interventions, it is not yet clear what value the adoption of a nexus perspective has for understanding governance or informing public policy (Weitz et al., 2017). Wichelns (2017) questions the novelty and wisdom of research or policy focusing specifically on interactions of water, energy and food, pointing out that many other links seem to be more important to consider in specific cases. -Foran (2015) identifies limitations for analysis in the current emphasis on systems and complexity, and thus recommends strengthening how the social dimensions are conceptualized, for instance, by paying greater attention to discourse, interests and power. In this study we propose and illustrate a hybrid approach that combines insights from complex systems thinking on sustainability with analyses of how power is exeercised with the aim of contributing towards diagnostic approaches for understanding the effectiveness of governance arrangements (Ostrom, 2009; Young, 2010).

\section{Nexus perspective}

\subsection{Governance problems}

In our view, to be useful for analyzing governance, a nexus perspective should improve understanding of four problems.

First, and most obvious, is the problem of coordination. -In a nexus situation this is primarily about coordination of projects, programs and policy across sectors. At its simplest this means taking into account consideration significant links, such as when water storage and release operations of an energy project in a river basin has impacts on the water available for irrigation, and thus food production. This may be a lot harder than it sounds. Institutional constraints in how energy, water or food are provided that arise from long histories of control and contestation, may be very hard to shift (Foran, 2015). Water, energy and land bureaucracies work with their own logics and their own scales (Pahl-Wostl, 2019). In the Upper Blue Nile in Ethiopia, for instance, coordination problems persist despite networks linking actors in different sectors, possibly because_of they are 'embedded' in pervasive hierarchical structures within sectors (Stein et al., 2018). In international settings, the links of concern across sectors may be transboundary, and policy coordination influenced by ideas and networks rather than conventional lines of authority (Haas, 1992), as well as the influence of regional organizations (Dombrowsky and Hensengerth, 2018).

Second, is the problem of anticipation. Under a nexus perspective this starts with the recognition that the significance of particular nexus links may not be well understood, and thus consultations or assessments may be needed before policies or projects proceed. One common goal is to try and make tradeoffs (and synergies) explicit (Colloff et al., 2019). In practice, this can be challenging as the importance of taking into account a particular nexus link in policy development or project design may itself be disputed. In the Lower Colorado River Basin geo- 
complexity and history, for instance, have produced a set of rigid laws that no longer reflect patterns of water use arising from urbanization (Huckleberry and Potts, 2019). processes may help improve mutual understanding of differences in interpretation and interests, \% 2012) connections between places, people and resources systems at multiple scales become relevant, the possibilities of non-linear change and surprises increases, making forecasts of future conditions, or the efficacy of particular governance interventions, difficult to project.

Third, is the problem of inclusion. People differ with respect to access to water, food and energy resources $_{2}$ as well as risks and scarcity created by powerful actors modifying nexus links. Failure to consider these inequalities when evoking nexus-inspired analyses in the Yakima River Basin, for example, led to results that maintained the status quo (Givens et al., 2018). Thus, Tthis should be taken into account in policy development and project design. Deliberative processes may help improve mutual understanding of differences in interpretation and interests, but not necessarily lead to consensus on complex issues (Dore et al., 2012). An important challenge is that not all individuals have the same opportunities to participate directly in research and assessment (Hoolohan et al., 2018), or otherwise influence decisions important to their lives (Allouche et al., 2015). But-However, it this is also -more than an issue of who participates: In managing flooded forests in Cambodia, integration efforts may be hindered when actors perceive a loss of power when they enter cooperative relationships (Bréthaut et al., 2019). Inclusive deliberations may help reduce normative uncertainties (Lebel et al., 2010) as nexus governance issues evolve and transform.

Fourth, is the problem of attribution. A nexus perspective recognizes that benefits and burdens or risks ${ }_{2}$ cross sectoral boundaries, and therefore issues of ownership and accountability are important. -Transparency with respect to project design, project operations, interests of stakeholders; and basis of key decisions (Larcom and van Gevelt, 2017), help strengthen accountability. Defining clear responsibilities for project impacts, include including those that were not anticipated,e is often neglected, reducing the legitimacy of authorities involved. In one sense the problem of attribution is the flipside of that of anticipation, with the former important before a project is undertaken and thate latter more so after it has been built. Either way, large infrastructure projects with multiple linked impacts, interact in complex ways, making attribution more challenging then for a single, small and isolated project.

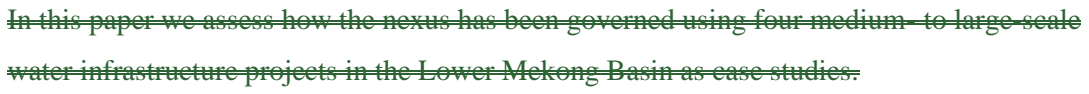

development projects-(Molle et al., 2009b), many of which have given rise onserns (Singer et al., 2014), (Baran and Myschowoda, 2009) 
and distribution befits-(Suhardiman et al., 2014)and burdens-(Kuenzer et al., 2013)‡We

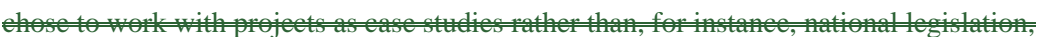

because of our theoretical interest in the social dimensions of the nexus. Projects, we suggest,

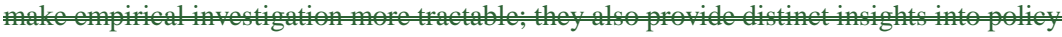
processes, non-state actors and outcomes on the ground, than a foeus just on government policy. The construction, operation and even de-commissioning was considered potentially relevant.

Attending to the four governance problems above, the first question we address is: How have the nexus governance problems been invoked and addressed by different policy actors?

\subsubsection{Nexus structurale and-_complexity}

Furthermore, and $d$ Drawing on systems thinking, we note that the scope of a nexus governance problems, as defined by actors themselves, vary substantially in structure; at its simplest, a pair of processes with one link, through a chain of several links, to even more complex sets of links with feedback loops (Table 1). Complex systems with several interacting parts often exhibit non-linear and emergent behavior that can make pursuits of sustainability challenging (Levin, 1999; Norberg and Cumming, 2008). It should be underlined however, that a more complex structure or dynamics does not imply that a more complex regulatory framework is needed for effective governance; on the contrary, other more innovative steering mechanisms may be needed (Young, 2017).

Thus, o $9 u$ initial prediction is that governance problems around the water-energy-food nexus become more challenging as the perceived nexus structure becomes more complex_(Märker et al., 2018); more challenging governance problems, in turn, we suggest are less likely to be resolved, p-or producinge ambiguous outcomes, or lead to contested strategies to simplify their structure.

There are several reasons for this expectation. First, if links are few, powerful actors will be able to push for resolution as other stakeholders need not be engaged or their actions coordinated. Second, with loops the outcomes may become less predictable ${ }_{2}$ and thus create demands for more technical analyses to help anticipate significance of various links. Third, with more links and nodes there are likely to be more types of stakeholders and interests to include in deliberations and negotiations. Fourth, in more complex nexus structures ${ }_{2}$ lines of responsibility are blurred and attribution of blame more difficult to demonstrate. 
Thus, a multi-scale analysis of what it would involve to take into account the nexus in the case of Brazil concluded that the complexities involved were huge and demanded closer links between science and policy (Mercure et al., 2019). The second question we address is thus: Does the structurale or complexity of the nexus tinks evoked invoked by various actors have any bearing on governance ehallengesproblems, efforts or outcomes?

\subsection{Water infrastructure projects in the lLower Mekong Basin}

InTthis paper assesses and compares how the nexus has been governed using four mediumto large-scale water infrastructure projects in the Lower Mekong Basin as case studies (Figure $\underline{1)}$.

The Mekong Region is a suitable area for this study as it is the target of many water resources development projects (Molle et al., 2009b), many of which have given rise to concerns over resettlement (Singer et al., 2014), adverse impacts on fisheries (Baran and Myschowoda, 2009), and distribution of benefits (Suhardiman et al., 2014) and burdens (Kuenzer et al., 2013). We chose to work with projects as case studies rather than, for instance, national legislation, because of our theoretical interest in the social dimensions of the nexus. Projects, we suggest. make empirical investigation more tractable; they also provide distinct insights into policy processes, non-state actors and outcomes on the ground, than a focus just on government policy. The historical trajectory of a project from initial options assessment and plans through to construction, operation and even de-commissioning was considered potentially relevant. The cases were purposively selected based on their significant impacts on the nexus and varied political and institutional histories.

1.2

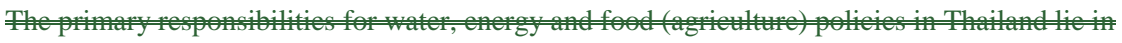
separate ministries with strategic planning bodies and area-based administration providing

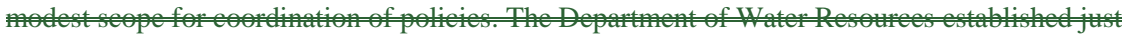

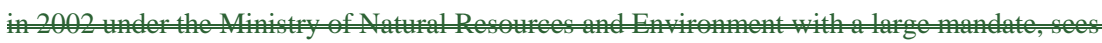
i level planning. The Electricity Generating Authority of Thatand is statenterprise under the Minity Department is under the Ministry of Agriculture and Cooperatives; it builds, supervises

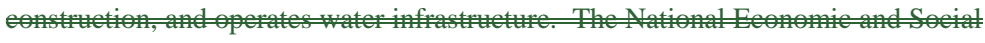

Development Board produces and oversees strategic longer-term plans. The Ministry of Interior h Authorities, and is thus crucial for development planning and implementation at subnational 
levels. The Ministry of Finance is less onspicums in public arenat but crucial project

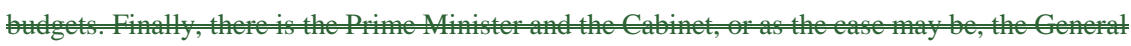
and key advisers.

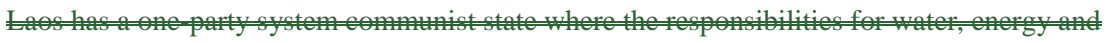

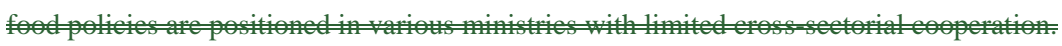
A

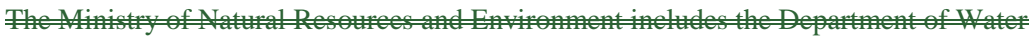
P water resources management in the Mekng mainstream and its 39 main tributaries in I 20 . The en

representing the Laogovernment in the Mekong River Commission's Joint Committee and

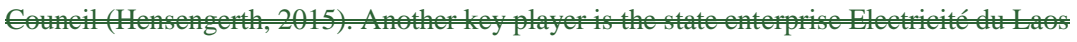
which owns and operates the country's electricity generation and transmission assets, while also

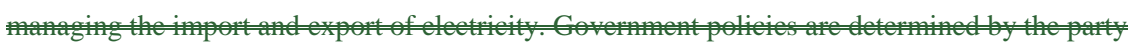
through the all-powerful nine-member Politburo of the Lao People's Revolutionary Party and 49 49 CO of Ministers; this includes the decisions on XBD and DSD.

The opportunities for civil society to engage in debates around large-scale water infrastructure projects has been much greater in Thailand than in Laos, although it has also varied with time in Thailand, being more restricted during periods of military rule.

The third, and final question we address is: How have differences in the institutional and political arenas of Laos and Thailand influenced nexus governance efforts and outcomes?

2 Methods

\section{Methods}

\subsection{Selection of Mekong case studies}

Two case studies are in Laos and two in Thailand (Map 1 and Table 2). In choosing the cases we sought diversity in the structural complexity of nexus links, institutional settings and governance efforts. Infrastructure projects to generate electricity and irrigate crops are appropriate cases for exploring nexus governance issues because they have direct and indirect implications for water, energy and food.

Pak Mun Dam (PMD) is a hydropower project completed in 1994, which-whereby more than two decades later remains a source of conflict over levels of compensation and dam operations. The Thai Water Grid (TWG) was a proposal for a very large-scale irrigation-oriented portfolio of projects announced in 2003, that built on earlier series of revolving mega-projects to 'green' 
the 'dry' northeast of Thailand, some parts of which like the Rasi Salai and Huana Dams, were built under the Khong-Chi-Mun project despite protests from local populations (Molle et al., 2009a). Although the TWG was 'abandoned' in 2006 after a military coup, the project idea has gone through several re-incarnations since.

Xayaburi (XBD) and Don Sahong (DSD) are the first two mainstream dams on the Lower Mekong. The Xayaburi dam-Dam is located in northern Laos and be-became operational in 2019. According to an interview with a senior official in the Lao government, XBD is expected to bring 130 million USD a year in royalties and taxes. Key developers of the project include Ch. Karnchang Public Company_,-Thailand's second largest publicly traded construction company), EGAT, the Lao government, and Ratchaburi Electricity Generating Holding Company. Following a Power Purchasing Agreement signed with the Electricity Generating Authority of Thailand in 2010, around 95\% of the electricity will go to Thailand. Since Thailand provides the financing, the labour force, the construction and buys the electricity, the project is often seen as a Thai project. The Don Sahong dam-Dam (DSD) is located in close proximity to the Cambodian border. Construction on the dam started in 2015 by the project's developer, Don Sahong Power Company, which is a joint venture between Mega First Corporation Berhad, a Malaysian company holding $80 \%$ and Laos' state-owned utility Electricite du Laos holding $20 \%$ with a concession for 25 years.

\subsection{Institutional and Political Setting}

The primary responsibilities for water, energy and food (agriculture) policies in Thailand lie in separate ministries with strategic planning bodies and area-based administration providing modest scope for coordination of policies. The Department of Water Resources established just in 2002 under the Ministry of Natural Resources and Environment with a large mandate, sees itself as the primary agency responsible for integrated water resources management and basinlevel planning. -The Electricity Generating Authority of Thailand is a state enterprise under the Ministry of Energy whichthat generates, transmits, buys and sells electricity. -The Royal Irrigation Department is under the Ministry of Agriculture and Cooperatives; it builds, supervises construction, and operates water infrastructure. -The National Economic and Social Development Board produces and oversees strategic longer-term plans. The Ministry of Interior houses the public administration hierarchy, as well as subnational Electricity and Waterworks Authorities, and is thus crucial for development planning and implementation at subnational levels. The Ministry of Finance is less conspicuous in public arenas, but crucial to project budgets. Finally, there is the Prime Minister and the Cabinet, or depending on the period, as the ease the General and key advisors.

Laos has a one-party system communist state where the responsibilities for water, energy and food policies are positioned in various ministries with limited cross-sectorial cooperation. 
Agriculture and fisheries (food sector) are covered by the Ministry of Agriculture and Forestry. The Ministry of Natural Resources and Environment includes the Department of Water Resources $_{2}$, which focuses on water issues including basin level management and integrated water resources management in the Mekong mainstream and its 39 main tributaries in Laos. The energy sector is covered by the powerful Ministry of Energy and Mines, now typically representing the Lao government in the Mekong River Commission's Joint Committee and Council (Hensengerth, 2015). Another key player is the state enterprise Electricité du Laos, which owns and operates the country'.'s electricity generation and transmission assets, while also managing the import and export of electricity. Government policies are determined by the party through the all-powerful nine-member Politburo of the Lao People' the 49-member Central Committee. Important government decisions are vetted by the Council of Ministers; this includes the decisions on XBD and DSD.

\subsubsection{Document selection}

We opted to draw evidence from documents rather than interviews because we were interested in exploring an approach to the analysis of nexus governance that could be systematically applied to multiple historical cases. Given our interest in key actors this meant it was important to consider statements made to the press as well as official project documents.

Selection of documents was purposive with the aim of including a balance of documents from newspaper articles, printed reports, journal articles and videos (Table 3). Key words used in the search engine were the project names (e.g. "Xayaburi Dam"). Sources included were selected based on referenced more often (high page rank), with higher relevancy in sorted lists, and to achieve a representative set by document type, and author group as well as time periods relevant to a particular project and country context (Table 3). Some differences between countries are related to different times the projects were a focus of attention (time scale). Exclusion criteria included: documents which were not in English; duplicates; had no useful content as they were too short; included nothing beyond reference to the project name; were power point presentations with little detail; or were links to websites with unstable content.- The main limitation of this document-oriented analysis is that we could not directly ask questions in-line with our framework; to a certain extent we were able to reduce the problem by selecting cases that have been well studied.

\subsubsection{Coding procedure}

NVIVO software was used to organize and code documents. The strategy for documents primarily about the project, or short pieces like newspaper articles, was to read the entire text; for documents where the cases were not the primary focus, searches on project names were used 
to zoom in on relevant material. -A coding tree was designed beforehand that covered: the content of project narratives, as well as critiques; the arenas in which they were articulated and by whom; evidence about the interests and agency of state and non-state actors involved or affected by the project; and, references to coordinationgovernance efforts or learning facilitated or hampered by governance architecture. Below these broad categories coding was done inductively based on themes identified on content of the text. Similar nodes with few instances were grouped, whereas nodes with many instances were sometimes recoded into more specific themes. Finally, selected key word searches were used to further populate some themes with additional evidence. These codings were used to document how the four nexus governance problems were invoked and addressed in the four case studies.

\subsection{Structural complexity notation}

In a subsequent round of analysis, the explicit structural notation illustrated previously in Table $\underline{1 \text { was then used to classify claims of impacts and actions (or governance efforts) by various }}$ actors regarding the structural complexity of nexus links. Where appropriate this notation was includedretained in reporting the results as a way to identify evidence relevant to answering research question 2 , and to get an indication of the prevalence of the different structural patterns across cases and governance problems.

observations under discourses category were re-grouped where relevant into different nexus relationships (see Table 1). In terms of increasing complexity these range from single links, through chains, to loops. The short symbols introduced previously in Table 1 will be used to indicate the structure of nexus claims or evidence in the results section, and thus aid in answering question 2 . 


\section{Problem of coordination}

A nexus perspective on the problem of coordination focusses on the interaction among sectors. -Impacts evoked may be one-step, and one-way, or include chains and loops (Table 13) that cut across national boundaries. Coordination may be hindered by competition among government Ministries or Departments within a country, as well as different distribution of interests among countries in transboundary nexus situations (Table 4).

\subsection{Bureaucratic competition}

The TWG project was severely hampered by inter-departmental and inter-ministerial competition for project budgets, making coordination in practice extremely difficult (Figure 21) In response to the initial call in 2003 for TWG, for example, the Royal Irrigation Department and Department of Water Resources came up with competing proposals to implement the scheme ${ }_{2}$ and then worked to undermine each other (The Nation, 2007b). -In the TWG case, the stumbling block in a way was in the first step of getting enough water, economically, into the system that the project would be even worth considering as a food benefit $\left(\mathrm{W}_{\text {Laos }} \rightarrow \mathrm{F}_{\mathrm{ag}}\right.$ ).

Proponents in the TWG case did not even win this first argument clearly, with critics including prominent ex-bureaucrats claiming the project was technically infeasible and economically unjustified. In addition, there were many issues about the impacts of diversions downstream $\left(\mathrm{W} \rightarrow \mathrm{F} \supset \mathrm{W}_{\mathrm{eco}} \triangleright \mathrm{F}_{\text {fish }}\right.$, that which had not even been preliminarily assessed; and potentially would have been huge.

In the TWG case competition for project budget allocations for construction between the Royal Irrigation Department and the Department of Water Resources delayed the TWG project long enough for the military coup-de-grace. One reporter noted that the water grid for "some irrigation workers, it is almost a dream come true" (Bangkok Post, 2004). Others noted its adherence to supply augmentation paradigm (The Nation, 2005a). In 2008, the Department of Water Resources proposed a large portfolio of recycled construction projects including tunnels under the Mekong from tributaries in Laos-(Bangkok Post, 2008); in 2013 plans for Khong-ChiMun basin 'development scheme' covering 13 provinces were announced following completion of a multi-million dollar study by consultants (Bangkok Post, 2013). Elements in tThe Department of Water Resources, the Royal Irrigation Department, and the Electricity Generating Authority of Thailand in facthad very similar interests, namely, construction. The lack of attention to resource use efficiency or demand-side considerations hampers constructive engagement with both hydropower $(\mathrm{W} \rightarrow \mathrm{E})$ and irrigation $\left(\mathrm{W} \rightarrow \mathrm{F}_{\mathrm{ag}}\right)$ nexus chains. 


\subsubsection{Transboundary negotiations}

While Cambodia and Vietnam were outspoken against the XBD until the end of 2012, because of concerns on fisheries $\left(\mathrm{W} \rightarrow \mathrm{E} \supset \mathrm{W}_{\mathrm{Cam}} \downarrow \mathrm{F}_{\text {fish }}\right.$ ) or water quality for agriculture

$\left(\mathrm{W} \rightarrow \mathrm{E} \supset \mathrm{W}_{\mathrm{Vie}} \sqcup \mathrm{F}_{\mathrm{ag}}\right)$, since then the rhetoric from both countries has waned. Some experts argue that the redesign of the XBD was shared bilaterally with Vietnam — although the Mekong River Commission itself did not receive the documents until July 2013. However, Vietnam's changed attitude was probably not due to the change of the design of the XBD; as one international expert said, 'I don't think that the new design, if they got it, played a major role.' Others argue that a bilateral deal between both countries was achieved, which could include other areas such as rubber plantation or logging along the border between Laos and Vietnam ${ }_{2}$ or the building of the Luang Prabang Dam by a Vietnamese developer. In the Vietnamese media, pressure against hydropower development still exists, however it does not specify the XBD anymore. Further, Vietnam conducted furtherprogresses with its studies in the Mekong delta Delta focusing on impacts from upstream dams. Overall, Vietnam does not have a strong standpoint against dam building ${ }_{2}$ because around $50 \%$ of the Mekong River flow, which comes from the Vietnamese Highlands, ${ }_{2}$ is blocked by dams built in Vietnam. In September 2013, Laos officially notified the Mekong River Commission (MRC) and member countries of its intention to build DSD. The six-month consultation process of the MRC for the dam officially started in July 2014. In early 2015 however, the MRC Council could not agree if the process should come to an end and transferred the decision to the respective governments (Gerlak and Haefner, 2017).

One thing which was not made clear in TWG was where all the water was supposed to come from. Experts had recognized from analyses of earlier grand schemes that the only real 'solution' was to divert water from the Mekong and major rivers or tributaries in neighboring countries. The diversions from the Mekong needed to supply these huge schemes were rarely talked about in international arenas: "the Water Grid quietly hoped to suck the water out of Laos. It planned to build dams on rivers in Laos, and pump the water through a pipe under the Mekong" (The Nation, 2007b). The "Thai" water grid was not just a "Thai" project. Thus, in the TWG -case proponents focused on the $\mathrm{W} \rightarrow \mathrm{F}$ nexus link; whereas critics and opponents questioned the first step $(\mathrm{W} \mid \mathrm{F})$ or extended the link into a loop $\left(\mathrm{W} \rightarrow \mathrm{F} \supset \mathrm{W}_{\text {eco }}\right)$._Impacts of diversions for the TWG on wetland-supported fisheries (W $\rightarrow \mathrm{F} \supset \mathrm{W}_{\text {eco }} \triangleleft \mathrm{F}_{\text {fish }}$ ) would likely have been substantial and were completely ignored. Impacts on soil salinization are another critical risk ignored by project proponents $\left(\mathrm{W} \rightarrow \mathrm{F} \supset \mathrm{W}_{\mathrm{eco}} \triangleleft \mathrm{F}_{\mathrm{ag}}\right)$. 


\subsubsection{Inter-ministerial committee and integrated plans}

The tactic adopted by the PM Thaksin to deal with this lack of unity within government around the TWG project was to create new inter-ministerial committees, run multi-stakeholder events and slot-in water grid wording in key planning documents_(Molle and Floch, 2008). After the 2006 coup and change in national leadership however, the grid began turning back into a basin. In parallel, attention turned to river basin committees for cross-sectoral coordination, a stance supported by the World Bank (World Bank, 2011), promoted by the National Water Resources Committee (Bangkok Post, 2010), and the National Economic and Social Development Board in the latest national plan (NESDB, 2012).

The Ministry of Energy in Thailand is one of the few government agencies to so far have explicitly acknowledged the water-food-energy nexus in formal reports (MOE, 2015a). In its energy outlook report it also points out the benefits of cooperation with irrigation and flood management agencies. Historically, when the PMD and TWG projects were first launched this logic was missing but as the projects continue to be controversial, efforts at integration remain relevant to nexus governance. The latest Power Development Plan as expected focuses on energy security against backdrop of increasing power demand; it does not discuss water security issues or the nexus ${ }_{2}$ but documents several new transmission projects to support power purchases from hydropower projects in Lao PDR (MOE, 2015b).

The 2011-2015 National Development Plan of the Lao government only mentioned food and energy security= and does not link them to each other or to the impact on water related issues. Horizontal (cross-sectoral) cooperation between the water, energy and food nexus in the Lao government are non- $t$ existent. Similarly, vertical cooperation between the different government levels (eg.e.g. local, district and national) is not visible in through the document analysis. Local communities are often encouraged not to comment or speak out on the projects. The power and interest lies within the Lao government, especially the Ministry of Energy and Mines.

At the international level the Mekong River Commission has convened various consultations and as well as assessment studies, like the Council Study, as well as-multi-project and multicountry plans like the Basin Development Plan. These have not had much influence on key decisions to proceed with the two projects in Laos, although they did trigger a formal process of notification and consultation (MRC, 2003) in the XBD and DSD cases, which were scoped to exclude transboundary influences of large infrastructure schemes. Policy strategies, integrated plans and cross-sectoral bodies are potentially important dimensions of project governance for dealing with coordination issues but have so far had limited effectiveness. 


\begin{abstract}
integrated development plans ineffective at guiding project design or infrastructure operation

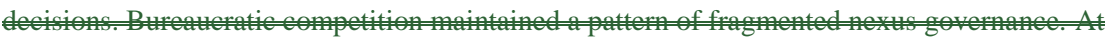

the international level, the Mekong River Commiscion has at mo planning
\end{abstract}

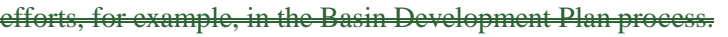

\title{
5 Problem of anticipation
}

A nexus perspective on the problem of anticipation focusses on claims and understanding of the importance of links before policies or projects proceed.

\subsection{Exaggerating benefits, minimizing risks}

In an interview in 1990 an official from the Electricity Generating Authority of Thailand argued that the PMD was useful to "ensure constant supply of electricity" $(\mathrm{W} \rightarrow \mathrm{E})$ and that it would contribute to the regional development and save bunker oil (Bunnag, 1990). As a 'run-of-theriver' dam authorities claimed it would not disrupt river flow or flood forest or homes (Phongpaichit and Baker, 1998). Proponents also argue that the dam site and design was chosen based on trade-off for "power generation on the one hand, and the need to minimize the dislocation and resettlement of households affected by the water level on the other" (TDRI, 2000). At some point in negotiating the project ${ }_{2}$ the Electricity Generating Authority of Thailand even claimed that only 39 families would be affected; ultimately the figures ran into the thousands (Bello et al., 1998). In practice, the run-of-river design meant that PMD does not generate all that much electricity and does so mostly in peak evening periods in the wet season (Chinvarakorn, 1999). It should be underlined that PMD was originally presented to NESDB and Cabinet in 1998 as a multi-purpose project (WCD, 2000). An initial feasibility study was revised to change the project from single purpose electricity generation to a multi-purpose dam project (Grachangnetara and Bumrungtham, 2003), illustrating how project narratives framed beneficial nexus links as being about water for energy and food $\left(\mathrm{W} \rightarrow \mathrm{E}\right.$ and $\left.\mathrm{W} \rightarrow \mathrm{F}_{\underline{a g}}\right)$. Expanding the benefits this way is a narrative strategy to broaden the coalition supporting the project. The irrigation benefits however ${ }_{2}$ were exaggerated in project documents and were not even included in some World Bank staff reports (TDRI, 2000) $\div$ nNevertheless, the government later installed small pump irrigation systems to bolster local support for irrigation components (Foran and Manorom, 2009). In the XBD and DSD irrigation plays a very minor role and the projects eannot should not be seen as multi-purpose-projects. 
The importance of the fisheries and threats posed to it by the construction of PMD were initially disputed $\left(\mathrm{W} \rightarrow \mathrm{E} \sqcup \mathrm{F}_{\text {fish }}\right.$ ) (Roberts, 1993). -The World Bank’s 1993 EIA confidently asserted that "Department of Fisheries and EGAT have several proven mitigation measures available to respond to any changes" (The Nation, 1999). A fish ladder was constructed by the developers to mitigate impacts on migratory fish. Villagers pointed out that the steep ladder is dry most of the year and if a "spawning fish succeed in climbing up the structure, if they ever do, they would already have had a miscarriage" "." (Chinvarakorn, 1999). The original plans for fish ladders on the XBD in Laos were also in Laos-controversial: fish experts argued that these initially designed ladders would not work due to the high diversity of fish in the Mekong, including different sizes and high number of fish, and the height of the dam (International Rivers, 2011).

The extent to which nexus links are extended into chains and loops depended on their perceived importance, narrative strategies, available arenas- and social-ecological context. Thus, claims and counter-claims about nexus chains and loops were more often made at the national level in the PMD case than the TWG case, a pattern that at first glance is counter-intuitive and requires explanation. In the PMD case a key strategy of opponents of the project was to take their complaints to the capital and make the governance of the project a national issue. In the TWG case, on the other hand, the project was national, but both proponents and critics sought influence at the provincial level to promote or criticize the project. Previous strong local opposition to dam projects in Thailand, including the PMD, helped drive involvement in hydropower development abroad mainly in Laos, where civil society is weaker. In the DSD and $\mathrm{XBD}_{\text {cases }}{ }_{2}$ actors mostly outside of Laos have drawn attention to altered flow regimes and the chain of impacts threateningen-fisheries $\left(\mathrm{W} \rightarrow \mathrm{E} \supset \mathrm{W}_{\text {eco }} \sqcup \mathrm{F}_{\text {fish }}\right)$.

Reactive governance can be attributed to authorities exaggerating the benefits from specific links from allocation of water for energy production $(\mathrm{W} \rightarrow \mathrm{E})$, or allocation to irrigation schemes for food production $(\mathrm{W} \rightarrow \mathrm{F})$, while ignoring adverse impacts of nexus loops and chains.

\subsection{Organized opposition makes neglected links visible}

The governance of the fisheries nexus loop $\left(\mathrm{W} \rightarrow \mathrm{E} \supset \mathrm{W}_{\text {eco }} \searrow \mathrm{F}_{\text {fish }}\right)$ in the PMD case is the best illustration of the merits and risks in such reactive governance 'mechanisms' like civil disobedience, alternative knowledge peroduction ${ }_{2}$ and sustained critiques that challenge the legitimacy of authorities and projects (Figure $\underline{3} z$ ).

In 1991 Civil Society Organizations in Thailand held hunger strikes and linked with transnational civil society groups to try and pressure other eeuntries-country representatives not to vote for release of loan for PMD by the World Bank. The Thai Finance Minister responded to 
the tactics, which caused a delay in financing by accusing foreign countries of interference (Stackhouse, 1991). The Ministry of Finance also told the Bank that "we can fund it ourselves. But we went to the World Bank precisely to make sure the dam was handled right" (Handley and Awanahora, 1991).

Once the PMD had been built, opponents focused on compensation claims for losses in fisheries. Essentially this can be interpreted as a way to seek redress for the negative impacts of the fisheries nexus loop $\left(\mathrm{W} \rightarrow \mathrm{E} \supset \mathrm{W}_{\mathrm{eco}} \searrow \mathrm{F}_{\text {fish }}\right.$ ). It was to be a long battle. A World Bank evaluation report in 1998 said there was "no conclusive evidence of any impact by Pak Mun Dam on the fish population, [and] fish catch levels" (Chinvarakorn, 1999). In 1999 an officer from the Electricity Generating Authority of Thailand interviewed-argued in an interview that "fisheries resources tend to decline naturally" and that the problem was therefore under "the jurisdiction of the Department of Fisheries" (Chinvarakorn, 1999). 'An early instance of what might be called 'passing the nexus baht'.

Another important tactic of affected people and supporting civil society organizations was to undertake their own assessments of impacts on fisheries or so called 'Thai baan', or village; research (Figure 3z) (Mekong Watch, 2004). One important area of local knowledge relates to patterns of migration of fish: "Old people say that when the owl cries, the fish come" (Mekong Watch, 2004). They understood the seasonal flood pulse and observed that "when we saw the Mun River affected by the water from the Mekong, migratory fish would ride the current and then come upstream",(Mekong Watch, 2004). The by then newly elected government under PM Thaksin directed a reluctant Electricity Generating Authority of Thailand to open $\theta$ f the sluice gates of PMD, initially for 4 months from May to August 2001, and then for one year to June 2002 so that an assessment of impacts on fisheries could be more directly measured and ecosystems restored (Figure $\underline{3 z}$ ) (Jutagate et al., 2005). The key recommendation of the assessment team in 2002 was that PMD should be opened all year round for five years (Bangkok Post, 2002). Since then villagers have unsuccessfully pressured for all year round opening (Saengpassa, 2011).

The NGO, Assembly of the Poor (AOP), staged several large protests in support of compensation and changes in operation of the PMD dam gates (Missingham, 2003). The Thai state responded to protests with a combination of 'repression and concessions' over two decades (Foran and Manorom, 2009). The notion of the village or local community became an important narrative, made physical, with the creation of a "Village of the Poor" opposite parliament house in the capital (Missingham, 2002). Since 1991 there have been numerous threats and acts of violence against the protestors (Elinoff, 2007). -As late as $2014_{2}$ activists who had taken part in protests in 2000 were charged for unconstitutional behavior and for holding illegal rallies, in cases filed by the Electricity Generating Authority of Thailand (Bangkok Post, 2014). Ms. Sompong who led villagers in many of the PMD protests and was herself charged with treason 
and criminal conspiracy for protesting against the dam ${ }_{2}$ in a 2011_interview argued: "-_Why should the authorities treat us as criminals? If defending one'sone's rights and calling for rightful compensation are crimes, then I den't don't know how Thai society can continue".', (Saengpassa, 2011).

\subsection{Assessment work}

EIA and Strategic Environmental Assessments, in theory, could also be tools in governing nexus chains and loops in a more anticipatory and proactive rather than reactive way, and not as just "a legal obstacle to the development process" as it is seen by many large-scale infrastructure proponents (Tongcumpou and Harvey, 1994). The eriginal EIA for PMD was condemned by many non-state actors for starting construction prior to completion of the original EIA (Saengpassa, 2011), and the neglect of obvious environmental impacts such as destruction of rapids (Roberts, 1993), lack of information on livelihoods, and lack of public participation. The World Commission on Dams acknowledged that the original 1981 EIA "produced inadequate baseline information" and that given the changes in site and design by the time the project reached implementation "warranted a new EIA" (WCD, 2000). The EIA process in Thailand, when it has beenis a legal requirement, is used to provide projects a cloak of legitimacy. The Office of the National Environment Board "regards EIA as a tool for remedying adverse environmental impacts rather than the criteria for judging whether projects should go ahead or not" (Tongcumpou and Harvey, 1994).-Moreover, there is no judicial control, so opposition has to come from "public protest or demonstration" rather than, for example, litigation (Tongcumpou and Harvey, 1994). Assessments could help shift decisions from being purely interest-based to being also evidence-based. -The Lao government perspective _ _ which Thailand supports _ _ is that the engineers altered the XBD design to focus on the fish passages, which meant that the project could proceed. Since international pressure focused on fish passages $\left(\mathrm{W} \rightarrow \mathrm{E} \unlhd \mathrm{F}_{\text {fish }}\right.$, as opposed to resettlement or water flow, it was easy for the government to adjust this one area. The Finnish engineering company Pöyry carried out the Environmental Impact Assessment (EIA) and then was chosen by the Lao Government to become the lead engineering firm of the project. -This is a clear example of a 'conflict of interests' between roles (Haefner, 2016).

\subsection{Summary: Reactive}

In summary, governance of the nexus from the perspective of the behavior of state actors has been largely reactive. Projects were initially conceived with the primary link and benefit in mind and serious consideration of other chain or loop impacts in the nexus only came about after advocacy and pressure from affected groups. 


\section{Problem of inclusion}

The nexus perspective on the problem of inclusion focusses on the various ways different groups of people are included or excluded in consideration of water, food and energy insecurities.

\subsection{Big promises}

Proponents of the TWG promised it would "eradicate all water-related problems plaguing the country.": The project was branded as a key part of the government's “war on poverty”_(Strait Times, 2003). The TWG was truly gigantic: it proposed tripling the area of land under irrigation in Thailand by diverting water from other places with too much to those with not enough $\left(\mathrm{W} \rightarrow \mathrm{F}_{\mathrm{ag}}\right)$. The grid metaphor made it deceptively "easy to imagine water flowing all around the country as power now flows from the rows of great striding pylons down to the tangled cabling on every street" (The Nation, 2007b). The only problem with this narrative was reality: "The targets of the water grid are so ambitious that it strains the imagination to envision anything close to its realization" (Molle and Floch, 2008). A remarkable feature of the TWG was how the "terms of national interest and poverty alleviation were implicitly presented as an overriding priority. This contributed to crowd out any possible discussion on the relevance and costeffectiveness of the project" (Molle and Floch, 2008).

The Lao government's immediate aim is economic development $\div$. Aas stated by the former Lao Deputy Minister for Energy and Mines, Viraphonh Viravong, hydropower is important because it is clean, cheap an $\underline{\underline{X x}} \mathrm{~d}$ renewable, further affirming that " like 33\% to the natural capital of the wealth of Laos. And if Laos wants to leave behind its least developed country status by 2020, this is our only ehoice' choice" (The Nation, 2010). As in TWG, poverty reduction and modernization were promised benefits of DSD and XBD projects in Laos $\left(\mathrm{W} \rightarrow \mathrm{E}_{\Phi} \lambda \mathrm{F}_{\mathrm{ag}}\right)$. According to project owner Xayaburi Power Co Ltd, the project will earn Laos more than US\$100 million per year $\left(\mathrm{W} \rightarrow \mathrm{E}_{\$ \mathrm{Laas}}\right)$. And for the government, that economic windfall has the potential to improve the lives of the 6.8 million population; ““that's that's why when you visit any site of hydropower projects in Laos, you won't see anybody against it" ${ }_{-}^{\prime \prime}$ (The Nation, 2010). The electricity produced in Laos and purchased by Thailand also improves the latter's energy security $\left(\mathrm{W} \rightarrow \mathrm{E}_{\text {Thai }}\right.$ ). Vietnam also needs to satisfy its growing energy demand and relies on energy imports from Laos also, as well as a significant set of dams on the Mekong tributaries $\left(\mathrm{W} \rightarrow \mathrm{E}_{\mathrm{Viet}}\right)$.

\subsection{Staying within boundaries}

The negative impacts on aquatic ecosystems $\left(\mathrm{W} \rightarrow \mathrm{F} \supset \mathrm{W}_{\text {eco }}\right)$ and fisheries $\left(\mathrm{W} \rightarrow \mathrm{F} \supset \mathrm{W}_{\text {eco }} \triangleright \mathrm{F}_{\text {fish }}\right)$ from -DSD within Laos and further downstream in the Tonle Sap of Cambodia and Mekong 
Delta in Vietnam could be very significant ${ }_{2}$ and thus a risk to food security in Cambodia. Besides the impact on fisheries, the dam will also negatively impact on the few remaining endangered Irrawaddy Dolphins in Laos, which use a transboundary deep pool within $1 \mathrm{~km}$ of the construction site and attract many tourists to the Siphandone area. -Further reduction in the numbers or disappearance of the dolphins would also have a negative impact on the local population due to a reduction in tourism. Recently, newspaper articles already highlighted the decrease of tourists to the area. For instance, Vientiane Times reported in regards to the Siphandone area that "[we] normally see at least five vans on the weekend and at least two big bus tours per monthe, but where we now see very few vans and it's lucky to see one big bus in a month" (Vientiane Times, 2017). Moreover, rice production in the Mekong Delta in Vietnam would also likely be affected strongly by large-scale hydropower development, especially if it impacted dry season flows when risks of salinisation are high $\left(\mathrm{W} \rightarrow \mathrm{E} \supset \mathrm{W}_{\mathrm{eco}} \sqcup \mathrm{F}_{\mathrm{ag}}\right)$.

\subsection{No energy needed to go $\underline{\mathrm{U}}$-uphill struggles}

From the perspective of the nexus, one of the key problems with the water grid idea was energy needed to pump water to higher land ( $\mathrm{W} \rightarrow \mathrm{F}_{\mathrm{ag}} \lambda \mathrm{E}_{\text {pumps }}$ ). Many earlier projects by the Royal Irrigation Department had failed because farmers were not willing to pay for maintenance costs and local authorities did not have the funds to pay electricity bills. The expectation is that hydropower generation would also be part of the grid_(Bangkok Post, 2004), but this was not discussed much in public. Biofuel production in the Northeast Region is already significant ${ }_{2}$ and may expand more in the future with government targets and incentives. The water use by biofuel crops $_{2}$ and thus not available for other crops $\left(\mathrm{W} \rightarrow \mathrm{E}_{\mathrm{bio}} \supset \mathrm{F}_{\mathrm{ag}}\right)_{2}$ was also a neglected topic in the discussions for the TWG.

In the early phase of the PMD project the electricity authority remained focused on power generation $(\mathrm{W} \rightarrow \mathrm{E})$ and limited consideration of impacts worthy of compensation to within narrowly defined resettlement impact boundaries; much later the project's governance arrangements continued to exclude significant impacts on migratory species fisheries $\left(\mathrm{W} \rightarrow \mathrm{E}_{\text {barrier }} \nu \mathrm{F}_{\text {fish }}\right)$, including those uphill in the tributaries further upstream (Baird et al., 2019).

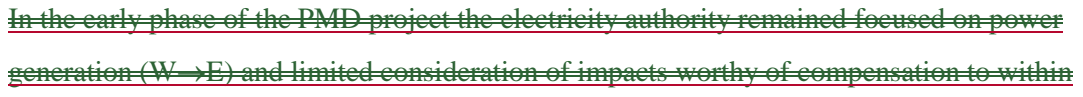

narrowly defined resettlement impact boundaries; much later the project's governance

2

$\left(\mathrm{W} \rightarrow \mathrm{E}_{\text {buriez }}=\mathrm{F}_{\text {fish }}\right.$, ineluling those in tributaries futher upstream (Baird et al., 2019). 
1

2

3

4

5

6.4 Summary: Exclusive

Projects were pursued and approved by policy elites with scant regard for the needs of vulnerable and affected groups, although poverty alleviation and other social benefits were a significant element in project narratives. 


\section{Problem of attribution}

A nexus perspective on the problem of attribution focusses on the responsibility for benefits, risks and burdens created by modifying nexus links.

\subsection{Avoiding responsibilities}

The DSD and XBD cases raise complex issues related to the interactions between water and food insecurities. The income generated for the Lao government $\left(\mathrm{W} \rightarrow \mathrm{E}_{\S}\right)$ could be used for infrastructure and agricultural development that would improve incomes and food security within Laos $\left(\mathrm{W} \rightarrow \mathrm{E}_{\$} \neg \mathrm{F}_{\mathrm{ag}}\right)$, however this is not a given as the money could also be spend-spent on other unrelated issues or for individual benefits. In the PMD case the initial project narratives were much simpler and modest, though overtime the project triggered elaborate counter narratives. In PMD case as the initial concern of project opponents was the impact of hydropower dam on agricultural livelihoods of those who had to relocate or whose river bank gardens would be destroyed $\left(\mathrm{W} \rightarrow \mathrm{E} \sqcup \mathrm{F}_{\mathrm{ag}}\right.$ ). The XBD project developers estimated that around 2,100 people would be resettled by the project, $_{2}$ and that more than 202,000 people living on the river banks in close proximity to the dam site would be affected through loss of income and food security (W $\rightarrow \mathrm{E} \sqcup \mathrm{F}_{\mathrm{ag}}$ ), including loss of agricultural land, loss of opportunities of gold panning and lack of access to forest products $\left(\mathrm{W} \rightarrow \mathrm{E} \triangleleft \mathrm{F}_{\text {for }}\right)$.

The Electricity Generating Authority of Thailand's interest in PMD was to keep energy and food (fish) issues separate $(\mathrm{W} \rightarrow \mathrm{E})$, ); in other words, not to acknowledge a longer nexus chain or loop $\left(\mathrm{W} \rightarrow \mathrm{E} \supset \mathrm{W}_{\text {eco }} \triangleleft \mathrm{F}_{\text {fish }}\right.$ ) that needed governance. The AOP on the other hand, based its advocacy on the links created by impacts of dam's construction and operations. When the Authority was ordered to open gates they lost revenue (W $\left.\searrow \mathrm{E}_{\$}\right)$; there are trade-offs "between power generation, wild-capture fisheries and water for pumped irrigation" which cannot be simply optimized as if there was no "political conversation" at play (Foran and Manorom, 2009). Now that there were both significant fishery and irrigator interests around $\mathrm{PMD}_{2}$ the controversy over opening and closing the sluice gates of PMD would seem to have become never-ending. One government's tactic was to shift the coordination "problem back to the locals to fight it out among themselves" by creating a new panel so that Cabinet would not have to deal with it each time (The Nation, 2007a). What might be called 'passing the nexus headache'.

\subsection{Hidden decisions}

A review of the PMD case study made by the Thailand Development Research Institute for the World Commission on Dams report in 2000 criticized the NESDB for failing to question the dam's economic feasibility despite a 70\% adjustment in costs (TDRI, 2000). The WCD report concludes that if done properly the project would probably not have gone ahead (WCD, 2000). In their 2001 Annual Report, the Electricity Generating Authority of Thailand writes that it 
"strives for greater efficiency and excelling in its business with accountability and transparency."-" The 11th National Economic and Social Development Board plan has an aspirational strategy in which an "efficient public administration must be enhanced through a thorough system of checks and balances" (NESDB, 2012). The TWG projects underlines that throughout the history of mega-projects in the northeast ${ }_{2}$ "no regime has managed to seriously devolve water resources management away from a central authoritarian planning paradigm to a more participatory and accountable mode of governance, despite rhetorical promises" (Blake, 2014). Neglecting the history of nexus failures $(\mathrm{W} \rightarrow \mathrm{F})$ with previous smaller-scale piped-grid schemes in Thailand is another line of evidence of low accountability of state authorities. At a very minimum, lessons about breakage and maintenance challenges (Pinkaew, 2004), difficulties in operating the new technology (Wongruang, 2005), problems in collection of fees (The Nation, 2005b), and high energy costs for pumping (Pinkaew, 2004) (W $\rightarrow \mathrm{F}_{\mathrm{ag}} \nearrow \mathrm{E}$ )- should have been learnt, and taken into account in the TWG proposal. The low fixed price Thailand pays for electricity generated from XBD is a different sort of accountability issue: how and why was such an agreement reached? The problem is that the appearance of nice transparent words on paper, while they may "build an image of credibility" (Molle, 2005), have not outlined a decision-making process that is any more open or accountable in practice.

Mechanisms which could help overcome opaque projects serving narrow interests include transparency about project plans and improved accountability for impacts of project developers. Transparency about plans for large-scale projects is important to build public trust and acceptance (The Nation, 2007b). Early on in the PMD dispute, residents complained or were confused about the lack of information regarding the planned construction (Foran and Manorom, 2009). The Royal Irrigation Department's proposal for the TWG was not made public; much of the decision-making was made in secrecy (Molle and Floch, 2008); what was not secret, was a scramble with little scrutiny. -The huge profits at stake distort the normal planning process, "bureaucrats, politicians, consultants, and contractors have mutual interests in blocking proper public scrutiny" (The Nation, 2007b). Doubts were raised about pipe specifications which seemed to "favour certain firms with close ties to politicians" (Bangkok Post, 2004). In 2010 a member of the National Water Resources Committee helping revive the TWG proposal told the media that: "“The government must seek the people's people's opinion on the scheme. Both negative and positive information about these projects must be made public." ". In 2015 residents in Loei were surprised to find out about the latest transboundary diversion project $_{2}$ and were disappointed that they were not consulted. From a nexus perspective, public participation and deliberation seem critical to identify causal chains; and to identify the winners and losers that emerge from nexus decisions (Middleton et al., 2015). It is not just about financial gain; it is also about the power to make decisions. 


\subsection{Pet projects}

Two individuals heading the Ministry of Natural Resources and Environment, with sharply contrasting storylines in the TWG case, underline that it is not only organizations that matter. Mr. Praphat Panyachartrak as Environment Minister was outspoken on the TWG and criticized the Ministry of Agriculture schemes (Kultida Samabuddhi, 2004). He was also a proponent for strengthening the EIA process. He was replaced. -His replacement ${ }_{2}:$ none other than-Deputy PM; Suwit Khunkitti, who in an earlier government had been the Agriculture Minister said on his first day, and who on his first day on duty-said "he favoured the 300-billion-baht project to lay a network of water pipelines nationwide" (Wipatayotin, 2011). -His position on the TWG is not surprising, as it followed on from its earlier position as as in many ways it was his 'baby' when he was the-Agriculture Minister. In 2011, many governments later, he was again the Environment Minister and again planning to expand the water grid project (Bangkok Post, 2011). Decisions on the TWG were driven by individual interests in re-election and organizational interests in re-directing money flows; water security was a secondary consideration.

\section{4-Stmmary: Opaque}

In summary, strategic planning and key project decisions take place behind closed doors while public consultation exercises added a little legitimacy. Decisions in the presence of significant trade offs appeared to align with powerful interests rather than broader social benefits. Policy elite and agency decisions to back or oppose projects can be explained by interests, power and money flows stpported by narratives that bound who is in and who is out. 


\section{Discussion}

The key finding from the four cases was that nexus governance was fragmented, reactive, exclusive and opaque. In summary, Ceoordination among ministries was limited with interministerial bodies and integrated development plans ineffective at guiding project design or infrastructure operation decisions. Bureaucratic competition maintained a pattern of fragmented nexus governance. At the international level, the Mekong River Commission has attempted to coordinate planning efforts, for example, in the Basin Development Plan process. Governance of the nexus from the perspective of the behavior of state actors has been largely reactive. Projects were initially conceived with the primary link and benefit in mind, and serious consideration of other chain or loop impacts in the nexus only came about after advocacy and pressure from affected groups. Projects were pursued and approved by policy elites with scant regard for the needs of vulnerable and affected groups, although poverty alleviation and other social benefits were a significant element in project narratives. In summary, strategic planning and key project decisions take place behind closed doors, while public consultation exercises added a little legitimacy.

-Decisions in the presence of significant trade-offs appeared to align with powerful interests rather than broader social benefits. Policy elite and agency decisions to back or oppose projects can be explained by interests, power, and money flows supported by narratives that bound who is in and who is out.

This situation arose because project proponents in both countries across all four cases - which always included key government agencies or state enterprises - articulated narratives around benefits from direct nexus links, and ignored or downplayed negative impacts arising from nexus causal chains and loops.-_Whether they got away with this 'shortening' strategy or not depended on the distribution of domestic political power, and to a lesser extent, international relations. These relational factors were highly context-sensitive, ${ }_{2}$ being contingent on broader political and economic struggles for influence over development agendas in Laos and Thailand.

Thus, there were also some important differences among projects in what sort of nexus politics they triggered. The two hydropower cases from Laos, XBD and DSD were similar to each other, with international attention focusing on the Prior Notification Prior Consultation Agreement process, as well as trying to understand bilateral deals made between partners or governments (Rieu-Clarke, 2014). Here $\Theta$ Opponents of projects typically adopted narrative strategies in which nexus links were turned into chains or loops, while proponents stayed focused on benefits; chains, if discussed, were about using income for sales of electricity to alleviate poverty and improve food security. The Thai hydropower case study (PMD) diverges from the Lao cases in that it deals with impacts that were confined to domestic setting and the post-construction period ${ }_{2}$ in which a reactive state engaged in a two-decade long tit-for-tat with opponents of a hydropower dam already built (Foran and Manorom, 2009). The PMD became 
an iconic case. -The irrigation mega-project (TWG) never happened-; a reactive, imploding state saw elite abandonment of a project that was unrealistic for anything other than attracting rural votes, an angle that became less relevant with military rule (Molle and Floch, 2008).

Governance arrangements for water, food and energy sectors, or more broad strategies and plans which help make nexus policies more coherent ${ }_{2}$ did not appear to matter very much for the key decisions made on large water infrastructure projects. Large projects have economic and political stakes that attract the attention of national leaders, senior bureaterats and other policy elites. Their interests, rather than evidence, set the boundaries of deliberations and elites are astute at invoking grand, apparently inclusive, narratives to justify such projects. Civil society challenges to the position of policy elites backing hydropower development in Laos seem limited, at least when compared to Thailand; and even- Myanmar (Kirchherr, 2018):$\amalg$ International processes convened by the Mekong River Commission have increased shared understanding of benefits and impacts (Suhardiman et al., 2015), but otherwise do not appear to have had much influence on decisions.

Overall, the structural complexity of the invoked or claimed nexus links were distributed similarly for the 4 governance problems. Thus, single links were involved in a third to just under half of instances in all four problem types. One exception was that coordination problems tended to involve more loops, whilst attribution problems were more likely to be chains. This latter finding may reflect actor strategies towards steering efforts. Thus, $\mathrm{t}$ The findings also suggest that more complex nexus interactions, chains or loops, often led to ambiguous decisions, ignoring issues or a stalemate; whereas as-simpler links- were more likely to be resolved. Complexity is not a given; it is negotiated. Political actors, it should be underlined, also sought to lengthen or shorten the number of acknowledged links; though opportunities for domestic, non-state actors, to have such influence were limited in the projects in Laos. Large projects have stakes that attract attention of policy elites whose narratives define the boundaries of the nexus.

Interacting resource insecurities that the nexus approach helps highlight are likely to become more prominent in the future as the impacts of climate change unfold in the Mekong Region. Many more decisions to build large-scale water and energy infrastructure will be made; there will also be other significant decisions related to transport infrastructure and logistics or biofuel policies, which could impact land-use. This raises the practical issue about what could plausibly be done to make nexus governance more coherent, anticipatory, inclusive and accountable. Three suggestions follow-on from the analysis here with respect to large-scale, multi-year; infrastructure projects.

First, is to create pro-active inter-Ministerial and multi-stakeholder bodies that focus on policy and planning coordination around large projects. In the case of Thailand, the NESDB would 
seem to be an appropriate convener and facilitator of such bodies. -The key point from experiences evaluated here is that these bodies should start work early, as soon as emerging issues arise, and not as reactions to a nexus crisis from a project already built or agreed on. At the international level, existing coordination mechanisms have primarily been about information sharing; a possible next step towards more sustainable trajectories would be to negotiate more ‘ambitious' shared goals (Young, 2017).

Second, and in-line with calls of many actors critical of the projects, there is a need for openingup the decision-making process to public scrutiny. Simple measures include making project proposals and plans easily accessible to the public (and other government agencies) early on in theearly in the option-exploration phase of the process $_{2}$, and declaring the criteria which will be used to identify and assess options. Assessments can help anticipate potentially critical nexus links and prepare stakeholders for non-linear changes and surprises.

Third, is to improve the accountability of authorities once a decision is made to go ahead. -This is about monitoring and following-up on promises made and detecting unanticipated problems early on so they can be addressed. -It is likely that multiple accountability mechanisms are needed-; for politicians, open and free elections are helpful, while for bureaucrats $s_{2}$ internal and external 'performance' not just 'accounting' audits are needed and should be made public. Clear attribution of responsibilities, shared or otherwise, need to be included from the start. This is critical given the increasing complexity of nexus links makes it hard to later attribute blame.

This study included two methodological choices that warrant reflection. First, was the use of projects as probes to understand nexus governance. Second, was the systematic description of water-energy-food nexus links and configuration, grouped into pairs, chains or loops. These two simplifications together create opportunities for systematically testing claims about merits of different types of interventions aimed at 'improving' nexus governance across a diverse range of social-ecological contexts. With only 4 project case studies we did not exploit this advantage fully, reducing the possibility of generalizations, for instance, around different interaction configurations or links that involved material flows versus symbolic or social connections (Covarrubias, 2019). -Another limitation of the notation used to describe nexus links is that it does not easily show different strengths or the dynamics, for instance, associated with seasonality, nor does it distinguish clearly, material and social links. Finally, taking individual projects as cases, if not careful, may limit analytical attention to cumulative impacts and also inadvertently simplify the relevant set of nexus links.

Moving beyond the Lower Mekong Basin and other comparable developing region contexts, we offer three specific propositions about the governance of the nexus around large scale water, energy or food projects deserving further investigation. These draw upon our simple distinction between nexus links, chains and loops. First, proponents of projects will attempt to lengthen 
nexus chains when describing benefits and shorten them when dealing with adverse impacts; opponents of projects will tend to do the opposite. -Second, the effectiveness of different institutional designs for coordination across sectors - such as integrated planning agencies, inter-ministerial committees, or EIA processes - which somehow could take into account nexus chain links (Pahl-Wostl, 2019), depends greatly on the size of project budgets, the time-frame for their completion and accountability of authorities involved. Third, policy stakeholder narratives which depict actors as villains, victims or heroes-are more influential than costbenefit analyses or lists (Lebel and Lebel, 2018); on decisions made around large infrastructure projects, ${ }_{2}$ ith multiple nexus chain links for which integration across sectors appears critical for sustainability (Leong and Mukherjee, 2015).

\section{Conclusions}

9

In conclusion, this study showed that the nexus governance in the Mekong region-Region of large infrastructure projects is often fragmented, reactive, exclusive and opaque.

Governance arrangements for water, food and energy sectors, or broader strategies and plans -which help make nexus policies more coherent - did not appear to matter for the key decisions made on large water infrastructure projects. Large projects have economic and political stakes that attract the attention of national leaders, senior bureaucrats and other policy elites. Their interests define the boundaries of deliberations and, their narratives how performance should be judged. Structural complexity of the nexus makes governance problems even more challenging 


\section{References}

Allouche, J., Middleton, C., Gyawali, D. (2015) Technical Veil, Hidden Politics: Interrogating the Power Linkages behind the Nexus. Water Alternatives 8, 610-626.

Baird, I.G., Manorom, K., Phenow, A., Gaja-Svasti, S. (2019) What about the tributaries of the tributaries? Fish migrations, fisheries, dams and fishers' knowledge in North-Eastern Thailand. International Journal of Water Resources Development, 1-30.

Bangkok Post, (2004) Irrigation head airs doubts on proposed national grid (3 May 2004), Bangkok Post,.

Bangkok Post, (2010) Water grid scheme lashed (2 January 2010), Bangkok Post, Bangkok Bangkok Post, (2011) Water management plan may be expanded in Isan (3 May 2011), Bangkok Post.

Bangkok Post, (2013) DWR unveils strategy to ease droughts in Northeast (30 April 2013), Bangkok Post, Bangkok.

Bangkok Post, (2014) Dam activists slam charges (18 February 2014), Bangkok Post.

Baran, E., Myschowoda, C. (2009) Dams and fisheries in the Mekong Basin. Aquatic Ecosystem Health \& Management 12, 227-234.

Bello, W., Cunningham, S., Poh, L.K. (1998) A Siamese Tragedy: Development and Disintegration in Modern Thailand. White Lotus, Bangkok.

Blake, D., (2014) Halt to water megaprojects offers hope, Bangkok Post, Bangkok.

Bréthaut, C., Gallagher, L., Dalton, J., Allouche, J. (2019) Power dynamics and integration in the water-energy-food nexus: Learning lessons for transdisciplinary research in Cambodia. Environmental Science and Policy 94, 153-162.

Bunnag, A., (1990) Energy shortages spark additional threat to livelihoods in Northeast (29 January 1990), Bangkok Post, Bangkok.

Cairns, R., Krzywoszynska, A. (2016) Anatomy of a buzzword: The emergence of 'the waterenergy-food nexus' in UK natural resource debates. Environmental Science \& Policy 64, 164170.

Chinvarakorn, V., (1999) Pak Mun Dam: still waters run deep (2 June 1999), Bangkok Post. 
Colloff, M.J., Doody, T.M., Overton, I.C., Dalton, J., Welling, R. (2019) Re-framing the decision context over trade-offs among ecosystem services and wellbeing in a major river basin where water resources are highly contested. Sustainability Science 14, 713-731.

Covarrubias, M. (2019) The nexus between water, energy and food in cities: towards conceptualizing socio-material interconnections. Sustainability Science 14, 277-287.

Dombrowsky, I., Hensengerth, O. (2018) Governing the water-energy-food nexus related to hydropower on shared rivers-the role of regional organizations. Frontiers in Environmental Science 6

Dore, J., Lebel, L., Molle, F. (2012) A framework for analysing transboundary water governance complexes, illustrated in the Mekong Region. Journal of Hydrology 466, 23-36.

Elinoff, E., (2007) Years of cruel treatment may have pushed Pak Mun villagers to the brink (21 July 2007), The Nation, Bangkok.

Foran, T. (2015) Node and regime: Interdisciplinary analysis of water-energy-food nexus in the Mekong region. Water Alternatives 8.

Foran, T., Manorom, K., (2009) Pak Mun Dam: Perpetually Contested?, in: Molle, F., Foran, T., Käkönen, M. (Eds.), Contested Waterscapes in the Mekong Region: Hydropower, Livelihoods and Governance. Earthscan, London, pp. 55-80.

Gerlak, A.K., Haefner, A. (2017) Riparianization of the Mekong River Commission. Water International 42, 893-902.

Givens, J.E., Padowski, J., Guzman, C.D., Malek, K., Witinok-Huber, R., Cosens, B., Briscoe, M., Boll, J., Adam, J. (2018) Incorporating social system dynamics in the Columbia River Basin: Food-energy-water resilience and sustainability modeling in the Yakima River Basin. Frontiers in Environmental Science 6.

Grachangnetara, S., Bumrungtham, P. (2003) Pak Mun Dam revisited. TDRI Quarterly Review $18,5-12$.

Haas, P.M. (1992) Epistemic communities and international policy coordination. International Organization 46.

Haefner, A. (2016) Negotiating for Water Resources: Bridging Troubled Waters. Routledge, New York.

Handley, P., Awanahora, S., (1991) Power struggles: Thai dam scheme causes split between rich and poor countries, Far Eastern Economic Review. 
Hoolohan, C., Larkin, A., McLachlan, C., Falconer, R., Soutar, I., Suckling, J., Varga, L., Haltas, I., Druckman, A., Lumbroso, D., Scott, M., Gilmour, D., Ledbetter, R., McGrane, S., Mitchell, C., Yu, D. (2018) Engaging stakeholders in research to address water-energy-food (WEF) nexus challenges. Sustainability Science 13, 1415-1426.

Huckleberry, J.K., Potts, M.D. (2019) Constraints to implementing the food-energy-water nexus concept: Governance in the Lower Colorado River Basin. Environmental Science and Policy 92 , 289-298.

International Rivers, (2011) The Xayaburi Dam: A looming threat to the Mekong River. International Rivers, Berkeley CA.

Jutagate, T., Krudpan, C., Ngamsnae, P., Lamkom, T., Payooha, K. (2005) Changes in the fish catches during a trial opening of sluice gates on a run-of-the river reservoir in Thailand.

Fisheries Management and Ecology 12, 57-62.

Keskinen, M., Guillaume, J.H.A., Kattelus, M., Porkka, M., Räsänen, T.A., Varis, O. (2016)

The water-energy-food nexus and the transboundary context: Insights from large Asian rivers. Water (Switzerland) 8.

Kirchherr, J. (2018) Strategies of Successful Anti-Dam Movements: Evidence from Myanmar and Thailand. Society \& Natural Resources 31, 166-182.

Kuenzer, C., Campbell, I., Roch, M., Leinenkugel, P., Tuan, V.Q., Dech, S. (2013)

Understanding the impact of hydropower developments in the context of upstream-downstream relations in the Mekong river basin. Sustainability Science 8, 565-584.

Kultida Samabuddhi, (2004) Proposed projects earn Somkid's praise, Bangkok Post.

Larcom, S., van Gevelt, T. (2017) Regulating the water-energy-food nexus: Interdependencies, transaction costs and procedural justice. Environmental Science and Policy 72, 55-64.

Lebel, L., Grothmann, T., Siebenhuner, B. (2010) The role of social learning in adaptiveness: insights from water management. International Environmental Agreements 10, 333-353.

Lebel, L., Lebel, B. (2018) Nexus narratives and resource insecurities in the Mekong Region. Environmental Science \& Policy 90, 164-172.

Leck, H., Conway, D., Bradshaw, M., Rees, J. (2015) Tracing the Water-Energy-Food Nexus: Description, Theory and Practice. Geography Compass 9, 445-460.

Leese, M., Meisch, S. (2015) Securitising sustainability? Questioning the'water, energy and food-security nexus'. Water Alternatives 8. 
Leong, C., Mukherjee, M. (2015) Managing the socio-ecology of very large rivers: Collective choice rules in IWRM narratives. Global Environmental Change 34, 172-184.

Levin, S. (1999) Fragile dominion: complexity and the commons. Perseus Publishing, Cambridge.

Märker, C., Venghaus, S., Hake, J.F. (2018) Integrated governance for the food-energy-water nexus - The scope of action for institutional change. Renewable and Sustainable Energy Reviews 97, 290-300.

Mekong Watch, (2004) A river, its fish and its people: Local knowledge of the natural environment at the mouth of the Mun river. Mekong Watchc.

Middleton, C., Allouche, J., Gyawali, D., Allen, S. (2015) The rise and implications of the water-energy-food nexus in Southeast Asia through an environmental justice lens. Water Alternatives 81, 627-654.

Missingham, B. (2002) The Village of the Poor Confronts the State: A Geography of Protest in the Assembly of the Poor. Urban Studies 39, 1647-1663.

Missingham, B.D. (2003) The Assembly of the Poor in Thailand: from local struggles to national protest movement. Silkworm Books, Chiang Mai.

MOE, (2015a) Thailand Energy Outlook 2015 [in Thai]. Ministry of Energy, Government of Thailand, Bangkok.

MOE, (2015b) Thailand Power Development Plan 2015-2036. Ministry of Energy, Bangkok.

Molle, F., (2005) Irrigation and water policies in the Mekong region: current discourses and practices. International Water Management Institute, Colombo, Sri Lanka.

Molle, F., Floch, P. (2008) Megaprojects and social and environmental changes: the case of the Thai "water grid". Ambio 37, 199-204.

Molle, F., Floch, P., Promphaking, B., Blake, D.J.H., (2009a) "Greening Isaan": Politics, Ideology, and Irrigation Development in Northeast Thailand. , in: Molle, F., Foran, T., Käkönen, M. (Eds.), Contested Waterscapes in the Mekong Region: Hydropower, Livelihoods and Governance. Earthscan, London, pp. 253-282.

Molle, F., Foran, T., Kakonen, M., (2009b) Contested waterscapes in the Mekong Region: Hydropower, Livelihoods and Governance. Earthscan, London, p. 426. 
MRC, (2003) Procedures for Notification, Prior Consultation and Agreement. Mekong River Commission, Phnom Penh.

NESDB, (2012) 11th National Economic and Social Development Plan 2012-2016 [in Thai]. National Economic and Social Development Board, Government of Thailand, Bangkok.

Norberg, J., Cumming, G.S., (2008) Complexity theory for a sustainable future. Columbia University Press, New York, p. 315.

Ostrom, E. (2009) A general framework for analyzing sustainability of social-ecological systems. Science $325,419-422$.

Pahl-Wostl, C. (2019) Governance of the water-energy-food security nexus: A multi-level coordination challenge. Environmental Science and Policy 92, 356-367.

Phongpaichit, P., Baker, C. (1998) Thailand's boom and bust. Silkworm, Chiang Mai.

Pinkaew, T., (2004) Completion of water grid not likely in five years (16 October 2004), Bangkok Post.

Rieu-Clarke, A. (2014) Notification and consultation procedures under the mekong agreement: Insights from the Xayaburi Controversy. Asian Journal of International Law 5, 143-175.

Roberts, T. (1993) Just another dammed river? Negative impacts of Pak Mun Dam on the fishes of the Mekong basin. Nat. Hist. Bull. Siam Soc. 41, 105-133.

Saengpassa, C., (2011) Death of a river (18 August 2011), Bangkok Post.

Singer, J., Pham, H.T., Hoang, H. (2014) Broadening stakeholder participation to improve outcomes for dam-forced resettlement in Vietnam. Water Resources and Rural Development 4, 85-103.

Smajgl, A., Ward, J., Pluschke, L. (2016) The water-food-energy Nexus - Realising a new paradigm. Journal of Hydrology 533, 533-540.

Stackhouse, J., (1991) Thousands of northern Thailand villagers who fear losing their homes and farms are protesting a controversial hydroelectric project. At stake is a \$54million World Bank loan (19 October 1991), Globe and Mail, Toronto.

Stein, C., Pahl-Wostl, C., Barron, J. (2018) Towards a relational understanding of the waterenergy-food nexus: an analysis of embeddedness and governance in the Upper Blue Nile region of Ethiopia. Environmental Science and Policy 90, 173-182. 
Strait Times, (2003) Thaksin vows to tackle Thailand's water problems. (26 July 2003), Singapore.

Suhardiman, D., Giordano, M., Molle, F. (2015) Between interests and worldviews: The narrow path of the Mekong River Commission. Environment and Planning C: Government and Policy 33, 199-217.

Suhardiman, D., Wichelns, D., Lebel, L., Sellamuttu, S.S. (2014) Benefit sharing in Mekong Region hydropower: Whose benefits count? Water Resources and Rural Development 4, 3-11. TDRI, (2000) Pak Mun Dam Case Study. Prepared for the World Commission on Dams. Thailand Development Researh Institute, Bangkok.

The Nation, (1999) Not a picnic for Pak Mool refugee (2 April 1999), The Nation, Bangkok.

The Nation, (2005a) Fight drought by conserving water (17 May 2005), The Nation, Bangkok.

The Nation, (2005b) Group calls for halt to projects (5 July 2005), The Nation, Bangkok.

The Nation, (2007a) Govt damned over Pak Mun (19 July 2007), The Nation, Bangkok.

The Nation, (2007b) Thailand's water management in a haze (19 March 2007), The Nation, Bangkok.

The Nation, (2010) Suwit seeks Bt50bn for irrigation project (18 February 2010), The Nation, Bangkok.

Tongcumpou, C., Harvey, N. (1994) Implications of recent EIA changes in Thailand. Environmental Impact Assessment Review 14, 271-294.

Villamayor-Tomas, S., Grundmann, P., Epstein, G., Evans, T., Kimmich, C. (2015) The waterenergy-food security nexus through the lenses of the value chain and the institutional analysis and development frameworks. Water Alternatives 8, 735-755.

WCD (2000) Dams and Development: A New Framework for Decision Making. World Commission on Dams, Cape Town.

Weitz, N., Strambo, C., Kemp-Benedict, E., Nilsson, M. (2017) Closing the governance gaps in the water-energy-food nexus: Insights from integrative governance. Global Environmental Change 45, 165-173.

Wichelns, D. (2017) The water-energy-food nexus: Is the increasing attention warranted, from either a research or policy perspective? Environmental Science \& Policy 69, 113-123. 
Wipatayotin, A., (2011) B850m grid study budget under fire (8 March 2011), Bangkok Post, Bangkok.

Wongruang, P., (2005) Grid system given thumbs down (7 July 2005), Bangkok Post.

World Bank, (2011) Integrated water resources management: A way forward, Thailand Environment Monitor. World Bank.

Young, O. (2017) Governing complex systems: social capital for the anthropocene. MIT Press, Cambridge, Massachusetts.

Young, O.R. (2010) Institutional dynamics: Resilience, vulnerability and adaptation in environmental and resource regimes. Global Environmental Change 20, 378-385. 
Table 1 Examples of different forms of nexus links from simple pairs through chains and loops. Interaction symbols are as follows: resource allocation $(\rightarrow)$, increases $(\nearrow)$, reduces $(\searrow)$, negative feedback loop $(\circlearrowleft)$, positive feedback loop $(\cup)$. E=energy. W=water. F=food. $\$=$ money. Bio=biofuel crops. Ag=agriculture. Eco=ecosystems. Dry=dry season

\begin{tabular}{|c|c|}
\hline Nexus links & Explanation \\
\hline \multicolumn{2}{|l|}{ PAIRS } \\
\hline $\mathrm{W} \rightarrow \mathrm{E}$ & Water allocated to hydro energy production \\
\hline $\mathrm{W} \rightarrow \mathrm{F}_{\mathrm{ag}}$ & Water allocated to irrigated agriculture \\
\hline \multicolumn{2}{|l|}{ CHAINS } \\
\hline $\mathrm{W} \rightarrow \mathrm{F}_{\mathrm{ag}} \lambda \mathrm{E}$ & Allocation of water for food increases energy needed for pumping \\
\hline $\mathrm{W} \rightarrow \mathrm{E} \searrow \mathrm{F}_{\mathrm{ag}}$ & $\begin{array}{l}\text { Water allocated to hydro energy production reduces suitability of flow river } \\
\text { bank gardens }\end{array}$ \\
\hline $\mathrm{W} \rightarrow \mathrm{E}_{\$} \lambda \mathrm{F}_{\mathrm{ag}}$ & Income earned from hydropower is allocated to agricultural development \\
\hline $\mathrm{W} \rightarrow \mathrm{E}_{\mathrm{bio}} \searrow \mathrm{F}_{\mathrm{ag}}$ & Water allocated to biofuel crops means less land for food crops \\
\hline $\mathrm{W} \rightarrow \mathrm{E} \searrow \mathrm{F}_{\text {fish }}$ & $\begin{array}{l}\text { Dams constructed for hydropower block upstream (and downstream) } \\
\text { migration of fish }\end{array}$ \\
\hline \multicolumn{2}{|r|}{ e } \\
\hline $\mathrm{W} \rightarrow \mathrm{F} \supset \mathrm{W}_{\text {eco }} \searrow \mathrm{F}_{\text {fish }}$ & $\begin{array}{l}\text { Water diverted for irrigation reduces quality of flow for aquatic and wetland } \\
\text { ecosystems important to fisheries }\end{array}$ \\
\hline $\mathrm{W} \rightarrow \mathrm{E} \supset \mathrm{W}_{\text {eco }} \searrow \mathrm{F}_{\text {fish }}$ & $\begin{array}{l}\text { Water allocated to hydro energy production reduces suitability of flow to } \\
\text { aquatic and wetland ecosystems reducing fisheries }\end{array}$ \\
\hline $\mathrm{W} \rightarrow \mathrm{E} \cup \mathrm{W}_{\mathrm{dry}} \lambda \mathrm{F}_{\mathrm{ag}}$ & $\begin{array}{l}\text { Water allocated to hydro energy production increases dry season suitability of } \\
\text { flow for irrigation }\end{array}$ \\
\hline $\mathrm{W} \rightarrow \mathrm{E} \supset \mathrm{W}_{\text {eco }} \searrow \mathrm{F}_{\mathrm{ag}}$ & $\begin{array}{l}\text { Water allocated to hydro energy production reduces suitability of flow to } \\
\text { agricultural lands with impacts on soil salinization and ground water that } \\
\text { impacts crop production }\end{array}$ \\
\hline
\end{tabular}


Table 2 Selected features of the four case studies examined in this paper.

\begin{tabular}{|c|c|c|c|c|}
\hline & $\begin{array}{l}\text { Pak Mun Dam } \\
\text { (PMD) }\end{array}$ & $\begin{array}{l}\text { Thai Water Grid } \\
\text { (TWG) }\end{array}$ & $\begin{array}{l}\text { Xayaburi Dam } \\
\text { (XBD) }\end{array}$ & $\begin{array}{l}\text { Don Sahong Dam } \\
\text { (DSD) }\end{array}$ \\
\hline \multicolumn{5}{|l|}{ Location } \\
\hline $\begin{array}{r}\text { Province } \\
\text { Country \& region }\end{array}$ & $\begin{array}{c}\text { Ubon Ratchathani } \\
\text { Northeast } \\
\text { Thailand }\end{array}$ & $\begin{array}{l}19 \text { Provinces } \\
\text { northeast Thailand }\end{array}$ & $\begin{array}{l}\text { Xayaburi Province } \\
\text { Northern Laos }\end{array}$ & $\begin{array}{c}\text { Champasak } \\
\text { Province Southern } \\
\text { Laos }\end{array}$ \\
\hline Rivers & $\begin{array}{l}\text { Mun River, } \\
\text { Mekong } \\
\text { Tributary }\end{array}$ & $\begin{array}{c}\text { Mekong } \\
\text { Mainstream and } \\
\text { Tributaries in } \\
\text { various countries }\end{array}$ & $\begin{array}{l}\text { Mekong } \\
\text { Mainstream }\end{array}$ & $\begin{array}{c}\text { Mekong } \\
\text { Mainstream }\end{array}$ \\
\hline $\begin{array}{l}\text { Status (mid- } \\
\text { 2017) } \\
\text { Construction } \\
\text { Period } \\
\text { Structure }\end{array}$ & $\begin{array}{l}\text { Operating } \\
1990-1994\end{array}$ & $\begin{array}{c}\text { Abandoned (2002- } \\
6) \\
\text { n/a }\end{array}$ & $\begin{array}{c}\text { Under } \\
\text { Construction } \\
\text { 2012-2019 }\end{array}$ & $\begin{array}{c}\text { Under } \\
\text { Construction } \\
2015-2019\end{array}$ \\
\hline Height $(\mathrm{m})$ & 17 & & 33 & 32 \\
\hline Length (m) & 300 & & 820 & unknown \\
\hline Reservoir $\left(\mathrm{km}^{2}\right)$ & 60 & & 49 & \\
\hline $\begin{array}{l}\text { Cost (USD } \\
\text { billion) }\end{array}$ & 0.6 & $7-11$ & 3.8 & 0.5 \\
\hline Main Financing & World Bank & $\begin{array}{l}\text { Government of } \\
\text { Thailand }\end{array}$ & $\begin{array}{c}6 \text { Thai } \\
\text { Commercial Banks }\end{array}$ & Malaysian firm \\
\hline $\begin{array}{l}\text { Power } \\
\text { Generation } \\
\quad \text { Peak Capacity }\end{array}$ & & & & \\
\hline (MW) & $\begin{array}{l}36 \mathrm{MW} \\
280 \mathrm{GWh}\end{array}$ & n.d. & 1200 & 260 \\
\hline $\begin{array}{l}\text { Annual (GWh) } \\
\text { Irrigation }\end{array}$ & $280 \mathrm{GWh}$ & n.d. & 7400 & 2000 \\
\hline Area $\left(\mathrm{km}^{2}\right)$ & 250 & 1,200 & & \\
\hline
\end{tabular}

a- adjusted to 2017 
Table 3. Characteristics of documents analyzed for the case studies in Laos and Thailand

\begin{tabular}{rcc}
\hline & $\begin{array}{c}\text { Thailand } \\
(\mathrm{n}=147) \\
\%\end{array}$ & $\begin{array}{c}\text { Laos } \\
(\mathrm{n}=44) \\
\%\end{array}$ \\
\hline Document type & & \\
Newspaper Article & 69 & 32 \\
Printed Report & 13 & 23 \\
Journal Article & 7 & 25 \\
Video & 0 & 16 \\
Other & 11 & 4 \\
Author type Reporter & 67 & 29 \\
Rcademic & 12 & 25 \\
Acavernment/firm & 10 & 2 \\
CSO & 6 & 32 \\
Other & 5 & 12 \\
& & \\
Year $1990-2004$ & 46 & 2 \\
$2005-2009$ & 30 & 5 \\
$2010-2014$ & 17 & 34 \\
$2015-2017$ & 7 & 59 \\
& & \\
\hline
\end{tabular}


Table 4. Illustration of nexus governance problems at the project level

\begin{tabular}{|c|c|c|c|c|}
\hline $\begin{array}{l}\text { Governance } \\
\text { Problem }\end{array}$ & $\begin{array}{l}\text { Pak Mun Dam } \\
\text { (PMD) }\end{array}$ & $\begin{array}{l}\text { Thai Water Grid } \\
\text { (TWG) }\end{array}$ & $\begin{array}{l}\text { Xayaburi Dam } \\
\text { (XBD) }\end{array}$ & $\begin{array}{l}\text { Don Sahong Dam } \\
\text { (DSD) }\end{array}$ \\
\hline Coordination & $\begin{array}{l}\text { Electricity } \\
\text { authority ignores } \\
\text { fisher livelihoods } \\
\text { in planning }\end{array}$ & $\begin{array}{l}\text { Bureaucratic } \\
\text { competition } \\
\text { hinders interplay } \\
\text { within water sector }\end{array}$ & $\begin{array}{l}\text { Transboundary } \\
\text { mechanism weak } \\
\text { despite large } \\
\text { impacts }\end{array}$ & $\begin{array}{l}\text { Ministry of Energy } \\
\text { \& Mines } \\
\text { dominates }\end{array}$ \\
\hline Anticipation & $\begin{array}{l}\text { Flawed } \\
\text { assessment }\end{array}$ & $\begin{array}{l}\text { No consideration } \\
\text { of labor }\end{array}$ & $\begin{array}{l}\text { Narrow focus on } \\
\text { electricity } \\
\text { generation }\end{array}$ & $\begin{array}{l}\text { Narrow focus on } \\
\text { electricity } \\
\text { generation }\end{array}$ \\
\hline Inclusion & $\begin{array}{l}\text { Loss of fisheries } \\
\text { ignored }\end{array}$ & $\begin{array}{l}\text { Poverty alleviation } \\
\text { sbenefits oversold }\end{array}$ & $\begin{array}{l}\text { Poverty alleviation } \\
\text { benefits oversold }\end{array}$ & $\begin{array}{l}\text { Ignore impacts } \\
\text { transboundary }\end{array}$ \\
\hline Attribution & $\begin{array}{l}\text { Hidden decisions, } \\
\text { individual } \\
\text { interests }\end{array}$ & $\begin{array}{l}\text { Neglect history of } \\
\text { failures }\end{array}$ & $\begin{array}{l}\text { Limited } \\
\text { responsibility for } \\
\text { impacts }\end{array}$ & $\begin{array}{l}\text { Income generated } \\
\text { yields little local } \\
\text { benefit }\end{array}$ \\
\hline
\end{tabular}


Figure 1. Mekong region map including case studies. The boundaries of the Thai Water Grid project shown in green are approximate only.

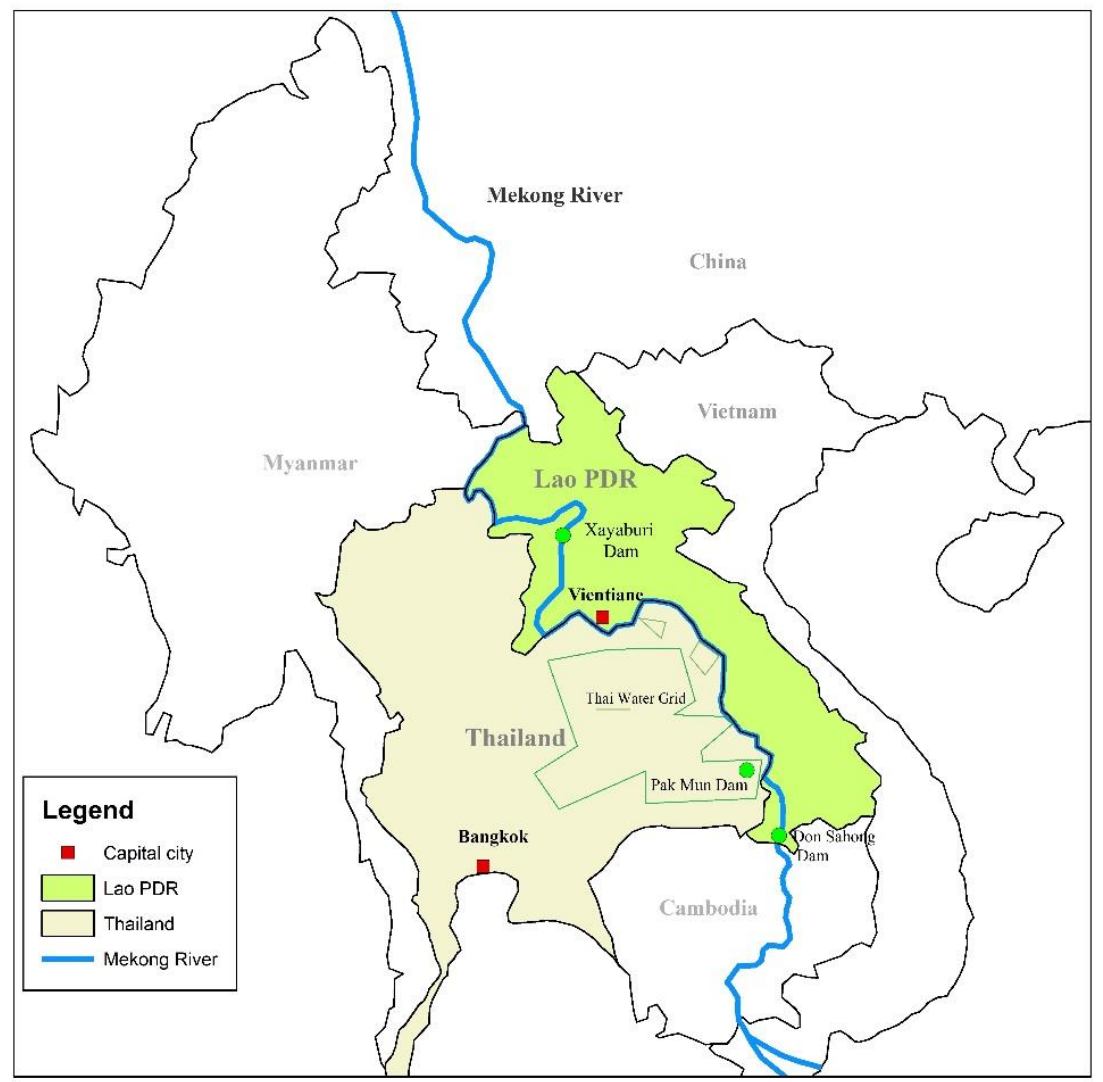


Figure 2. Illustration of some of the nexus coordination and contested knowledge issues from the TWG case.

\section{TWG}

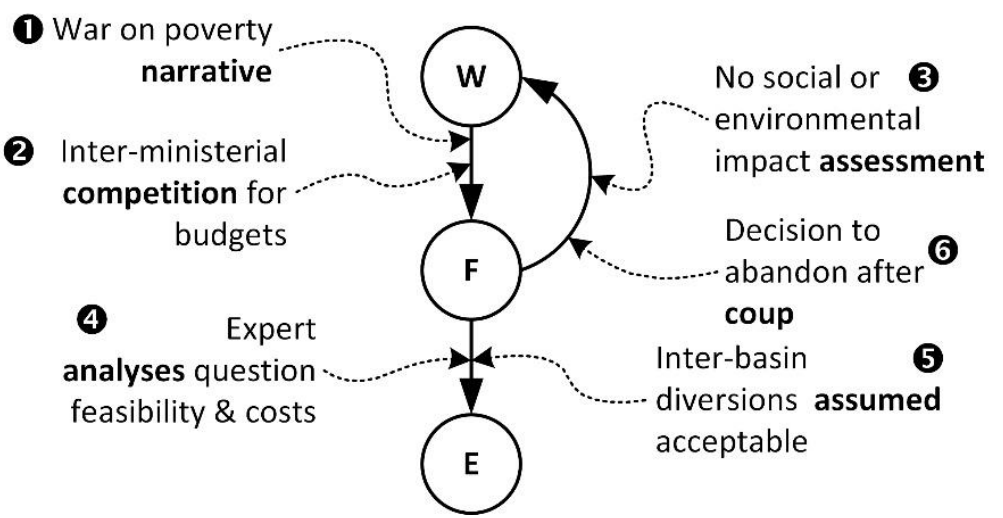


Figure 3. Illustration of some of the reactive nexus governance mechanisms in the PMD case.

PMD

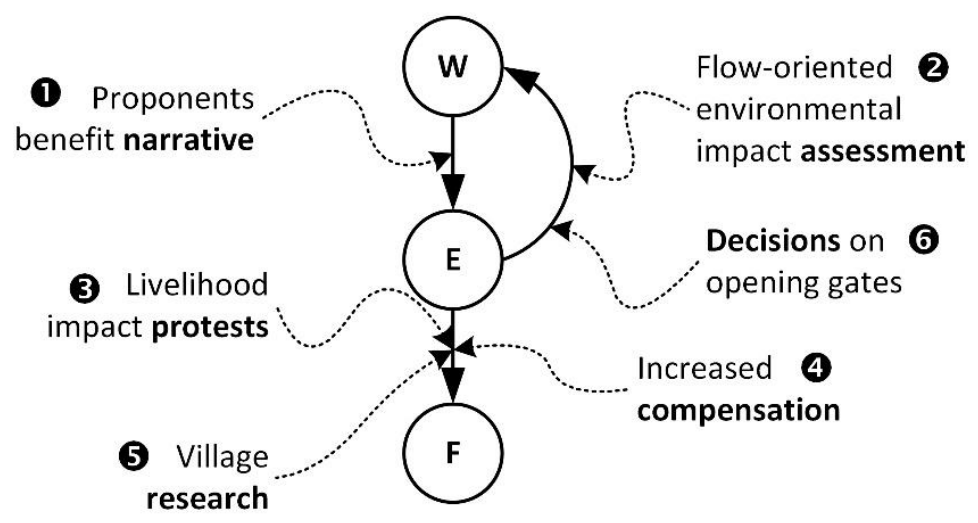

environmental

impact assessment

Decisions on 6

Increased 4

research 